\title{
Metastases of a Breast Cancer to Skull Base
}

\author{
Metastázy karcinomu prsu do baze lební
}

\author{
Horakova Z. ${ }^{1}$, Slavik M. ${ }^{2}$, Vesely K. ${ }^{3}$, Binkova H. ${ }^{1}$, Smilek P. ${ }^{1}$ \\ 'Department of otorhinolaryngology head and neck surgery, Faculty of Medicine, Masaryk University, St. Anne's University Hospital, Brno, Czech Republic \\ ${ }^{2}$ Clinic of radiation oncology, Masaryk Memorial Cancer Institute, Brno, Czech Republic \\ ${ }^{3}$ Department of pathology, Faculty of Medicine, Masaryk University, St. Anne's University Hospital, Brno, Czech Republic
}

\begin{abstract}
Summary
Background: Breast cancer (BC) is a frequent malignant disease which tends to develop distant metastases, but only very rarely in the head and neck region. Case report: We present two case reports of patients with metastases of invasive BC in this area. They are of different clinical manifestation with different time relation to the primary tumor and different symptomatology. In the case of the first patient, a few years without evidence of malignant disease after treatment of primary tumor in complete remission. In the case of the second patient, as the first symptom of undiagnosed disease. Metastases were clinically observed in the skull base and maxillary sinus, manifesting neurologically with foramen jugulare syndrome and orbital symptoms, resp. In both cases, correlations between histological and clinical findings were essential for diagnosis. Palliative multimodal treatment was then employed. Conclusion: Metastases of BC in the head and neck region occur only very rarely. The extremely variable symptomatology depends on the location of the metastasis and the affected structures. This might be a pitfall for diagnostics, especially in cases of an unidentified primary breast tumor, which may result in a delay of correct diagnosis. In addition, the correlation between histopathological and clinical findings might be of great relevance in these cases.
\end{abstract}

Key words

skull base metastasis - breast cancer - foramen jugulare syndrome

\section{Souhrn}

Východiska: Nádor prsu patří mezi nejčastější nádorová onemocnění s tendency ke vzdálenému metastazování, nicméně metastázy do oblasti hlavy a krku jsou výjimečné. Pozorování: Prezentujeme dva prípady pacientek s metastázami invazivního karcinomu prsu do této oblasti. Každý je se vzájemně odlišnou klinickou manifestací. I v rozdílném čase ve vztahu k primárnímu nádoru. $V$ prvním případě po několika letech po léčbě primárního nádoru v kompletní remisi a v druhém př́padě jako první přiznak dosud nediagnostikovaného onemocnění. Metastázy se klinicky projevily do oblasti baze lební a maxilární dutiny neurologicky syndromem „foramen jugulare", resp. oční symptomatologií při metastáze do očnice. V obou př́ipadech byla zcela zásadní histologická diagnóza. Následovala multimodalitní terapie. Závěr: Projevy vzdálených metastáz karcinomu prsu do oblasti baze lebni mohou být velmi variabilní, tím se stávají velkou diagnostickou výzvou pro klinika. Obtí̌ná dostupnost některých lézí znesnadňuje diagnostiku, zejména v případech, kdy se jedná o první symptomatologii dosud neznámého primárního tumoru.

\section{Klíčová slova}

metastázy do báze lební - karcinom prsu - syndrom foramen jugulare
This study was supported by the grant of the Ministry of Health of the Czech Republic AZV 16-29835 and the grant of the Grant Agency of the Czech Republic GACR 16-12454S.

Tato studie byla podpořena grantem Ministerstva zdravotnictvi CR AZV 16-29835 a grantem Grantove agentury CR GACR 16-12454S

The authors declare they have no potential conflicts of interest concerning drugs, products, or services used in the study.

Autoři deklarují, že $v$ souvislosti s predmětem studie nemají žádné komerční zájmy.

The Editorial Board declares that the manuscript met the ICMJE recommendation for biomedical papers.

Redakční rada potvrzuje, že rukopis práce splnil ICMJE kritéria pro publikace zasílané do biomedicínských časopisů.

$\equiv$

MUDr. Hana Binková, Ph.D.

Department of otorhinolaryngo-

logy, head and neck surgery

Faculty of Medicine

Masaryk University

St. Anne's University Hospital

Pekařská 664/53

65691 Brno

e-mail: binkova.ha@seznam.cz

Submitted/Obdrženo: 23. 2. 2018

Accepted/Přijato: 21. 4. 2018

doi: 10.14735/amko2018293 


\section{Introduction}

Breast cancer $(\mathrm{BC})$ is the most frequent malignancy in women $-25 \%$ of all newly diagnosed tumors, with an increasing incidence. Although there is decreasing mortality, the incidence of distant metastases has been increasing in recent years, perhaps as a consequence of better treatment results and prolonged overall survival $[1,2]$. On the other hand, metastases to the head and neck area are still rare and occur at an advanced stage. However, some cases have been published in which symptomatology brought on by such metastases was the first symptom of a previously undiagnosed tumor.

\section{Case 1}

A 53-year-old female with history of a former invasive ductal carcinoma of the left breast grade 2, pT2N2a (4/22) M0, ( $\mathrm{SR}+, \mathrm{HER} 2-)$ after radical mastectomy adjuvant, adjuvant chemotherapy, radiotherapy and hormonal therapy, without evidence of disease for the last 5 years.

During follow up, she suddenly experienced mild swallowing difficulties and a foreign body sensation in the throat. Flexible laryngoscopy showed a slight impairment of vocal cord mobility. After 6 months, there was a sudden worsening of hoarseness and an attack of vertigo, accompanied by nausea, vomiting, hearing loss and tinnitus, paresthesia in the right arm and impaired movement of

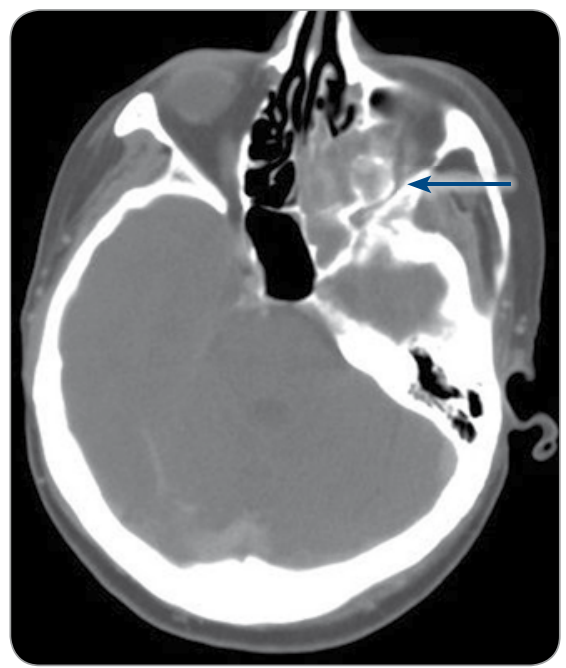

Fig. 1. CT prior to surgery with a metastasis in orbit. the right side of the body; in 15 minutes these troubles completely subsided. The patient was preliminarily diagnosed with a cerebral transitory attack in the vertebrobasilar region by the neurologist. ACT and MRI of the brain was performed, without evidence of ischemia; however, they revealed a new skull base pathology - destruction of the pyramidal apex caused by a lesion, size $22 \mathrm{~mm}$, affecting the carotid channel, protruding into the middle ear cavity, destructing the posterior cranial fossa and the jugular foramen. A jugular glomus tumor had to be excluded (Fig. 1).

Otomicroscopy revealed a dark bluish mass behind the intact eardrum. Audiometry showed sensorineural hypacusis (threshold 40-70 dB) nystagmus III. The left vocal cord was fixed paramedially. The patient was unable to extend her left arm above the horizontal (Disability no. VII, VIII, IX, X, XI).

Surgical exploration and biopsy were indicated. Tumorous tissue was removed (Fig. 2). Histology confirmed malignant tissue most likely compatible with metastasis of BC although ER-/PR-, perhaps due to an insufficient amount of representative biological material from the bony tissue.

PET detected another metastatic lesion in the scapula. Palliative radiotherapy $30 \mathrm{~Gy}$ in 10 fractions to the area of the skull base and left scapula was then employed. Complete remission was achieved in both involved sides. The patient remained on hormonal treatment for another 18 months when further disease progression appeared in the bones, a biopsy of which proved the metastasis of $B C$ with ER/PR positivity.

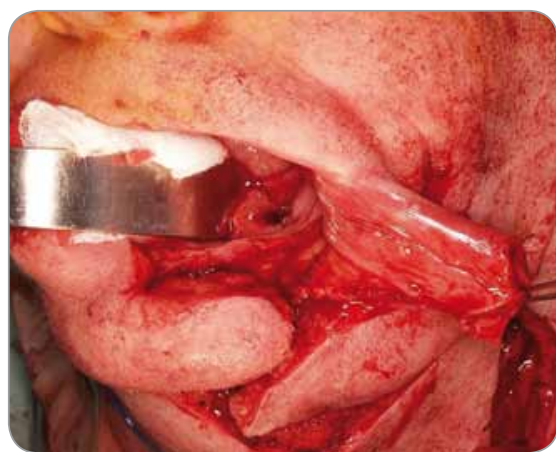

Fig. 2. Surgical access to a metastasis in scull base.

\section{Case 2}

A 65-year-old female presented with a progressive diplopia and blurred vision over the preceding 14 days, normal sight previously. Local finding - protrusion of left eye (5-6 mm); eyelid swollen, paretic eyeball in all directions, resembling orbital cellulitis, ENT local findings were negative.

CT - left ethmoidal sinuses completely filled in with dense mass, expanding to the left orbital roof with a dense tissue rim (approximately $5 \mathrm{~mm}$ ) and to the nasal cavity, thickening of the bone of the orbital apex and multiple lymphadenopathy of the neck up to $20 \mathrm{~mm}$ (Fig. 3). Another unknown exulcerated tumor was revealed in the left breast, which the patient had recognized a few months earlier (of size $40 \times 50 \mathrm{~mm}$, with tough rim $100 \times 80 \mathrm{~mm}$ ). Other tumors were also confirmed on the $\mathrm{CT}$ - multiple in the lungs, mediastinal and retroperitoneal nodes, liver and bones.

A biopsy sample was taken under endoscopic control from the fragile tissue completely filling the posterior ethmoids, partly destructing the lamina papyracea.

Histology was compatible with invasive ductal breast carcinoma (HER2-, $\mathrm{ER+}$ ) and consistent metastasis to the ethmoids. Further examination with a kind of a "super scan" image revealed overall disseminated disease with multiple lung, liver and bone metastases. However, the only threatening symptoms were those involving

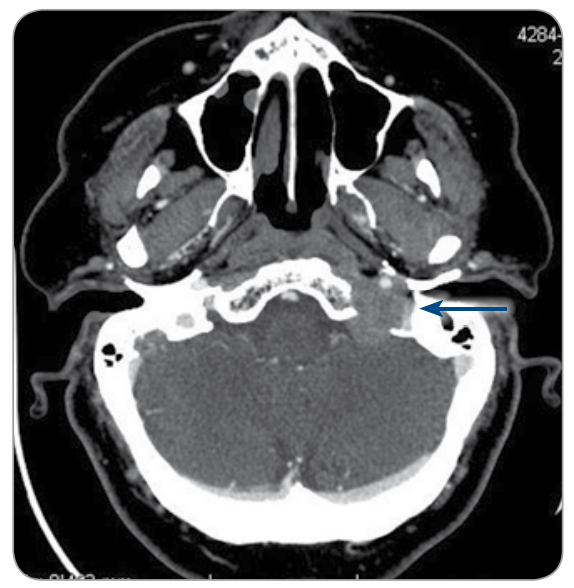

Fig. 3. CT prior to surgery with a metastasis to scull base. 
the base of the skull. Systemic weekly Taxol chemotherapy was recommended and a palliative radiotherapy aimed at the ethmoid sinuses was applied with good and enduring palliative effect. The patient received no additional treatment and died after 14 months due to tumor growth and overall disease progression outside of the skull base region.

\section{Discussion}

Here, we showed two different cases of $B C$ with metastasis to the head and neck (specifically, the base of the skull) region. The first case described the manifestation of the rare disease after 6 years of no disease activity, and the second case showed a most apparent and mutilating disease occurrence within an otherwise completely disseminated asymptomatic disease. Both cases were locoregionally advanced with multiple nodal involvement [1].

BC often metastasizes to bones, liver, and lungs, but only very rarely, and at an advanced stage, to the head and neck region. The prognosis of these patients is poor with expected shortterm survival (20-60 months). The most frequent histological type is an invasive ductal carcinoma, ER/PR+, HER2/Neu-, as it was in both of our cases.

There have been cases of metastasis to different areas of the head and neck (temporal bone, nasopharynx, larynx, parotid or paranasal sinuses) described in the literature $[3,4]$.

In the skull base, metastases usually occur in the parasellar region, in the middle fossa (Gasserian ganglion syndrome), occipital condyles, orbit and foramen jugulare. Metastases may be clinically silent for a long time or present themselves only by discreet neuropathy [5].

Orbital lesions present with diplopia, eyeball proptosis, eyelid swelling, pain, blurred vision, and ptosis of the upper eyelid.

Foramen jugulare symptoms may present variably according to affected structures. These include Werner syn- drome (dysphonia, dysphagia, pharyngeal pain - dysfunction of no. IX, X and $\mathrm{XI}$ ), Jackson syndrome (dysfunction of no. X, XI and XII), Collet-Sicard syndrome (dysfunction of no. IX-XII); Villaret's syndrome (impaired cervical sympathetic, Horner syndrome), and Tapia's syndrome (dysfunction no. $X$ and XII.).

Paranasal sinus (PNS) symptoms are non-specific, often very similar to common sinusitis (nasal obstruction, pressure and pain). More severe symptoms occur when tumor tissue infiltrates the orbit (diplopia, eyelid ptosis, blurred vision), as in our case.

More common origins of foramen jugulare syndrome (which must be excluded) are - benign tumors (paraganglioma, meningioma, and schwannoma), vascular abnormalities, congenital and inflammatory processes, cerebrovascular, infective or metabolic pathology. In case of malignant lesions, the most common are those of nodal metastases or continuously growing head and neck carcinomas. Distant metastases from the subclavicular primary tumors appear only very sparsely in above-mentioned areas.

Metastases to the skull base usually originate from the lungs or gastrointestinal or urogenital tract. Up to $15 \%$ of the cases are of an unknown primary origin [6].

In the sinonasal area, $96 \%$ of the malignant tumors are primary carcinoma. Over $70 \%$ of distant metastases originate from renal tumors, less frequently from gastrointestinal, lower respiratory tract, prostate or ovarian tumors.

Metastases from BC are very rare, occurring slightly more often in the skull base than in the PNS [7].

Detection on a CT is typical (saturating lesion, with skeletal destruction). MRI may be added (metastases are mostly hypointense on $\mathrm{T} 1$ and hyperintense on T2) [6].

The treatment is palliative in advanced disease stages. Surgery and radiother- apy are suggested, combined with systemic chemotherapy or hormonal therapy, with respect to the patient's performance status. Radiotherapy provides pain relief in up to $90 \%$ of patients and reduces other local symptoms. Better results are achieved in patients with rapidly progressing symptoms (less than 1 month). Surgical treatment - a palliative metastasectomy is indicated in the case of serious local symptoms.

\section{Conclusion}

Metastases of BC in the head and neck region occur only very rarely. The extremely variable symptomatology depends on the location of the metastasis and the affected structures. This might be a pitfall for diagnostics, especially in cases of an unidentified primary tumor, but these type of metastases are rather unexpected also in cases of identified primary tumors, which may result in a delay in correct diagnosis. In addition, correlation between histopathological and clinical findings might be of great relevance in these cases.

\section{References}

1. Raap M, Antonopoulus W, Dammrich M et al. High frequency of lobular breast cancer in distant metastasese to the orbit. Cancer Med 2015; 4 (1): 104-111. doi: 10.1002/cam4.331.

2. Schneider C, Fehr MK, Steiner RA et al. Frequency and distribution pattern of distant metastases in breast cancer patients at the time of primary presentation. Arch Gynecol Obstet 2003; 269: 9-12. doi: 10.1007/s00404-0020445-x.

3. Garcia TD, Molina QC, Sanz FR. Ethmoid metastasis of primary breast tumour. Acta Otorrinolaringol Esp 1998; 49(2): 163-164.

4. Pignataro L, Peri A, Ottaviani F. Breast carcinoma metastatic to the ethmoid sinus: a case report. Tumori 2001; 87(6): 455-457.

5. Flis DW, Shah AT, Tracy JC et al. Metastatic breast carcinoma of the jugular foramen: a rare case of Billaret syndrome. Head Neck 2015; 37(11): 146-149. doi: 10.1002/hed.24008.

6. Löwenheim H, Koerbel A, Ebner FH et al. Differentiating imaging findings in primary and secondary tumors of the jugular foramen. Neurosurg Rev 2006; 29(1): 1-11. doi: 10.1007/s10143-005-0420-7.

7. Wanamaker JR, Kraus DH, Eliachar l et al. Manifestations of metastatic breast carcinoma to the head and neck. Head Neck 1993; 15(3): 257-262. 